Tropical Journal of Pharmaceutical Research August 2017; 16 (8): 2039-2046

ISSN: $1596-5996$ (print); 1596-9827 (electronic)

(C) Pharmacotherapy Group, Faculty of Pharmacy, University of Benin, Benin City, 300001 Nigeria.

All rights reserved.

Available online at http://www.tjpr.org

Original Research Article

http://dx.doi.org/10.4314/tjpr.v16i8.39

\title{
Pharmacokinetics and tissue distribution of N-3- methoxybenzyl-palmitamide in rat: A macamide derived from Lepidium meyenii
}

\author{
Qihong Zhang ${ }^{1}$, Kaiqi $\mathrm{Wu}^{1}$, Yong $\mathrm{Xu}^{1}$, Saidan $\mathrm{Ding}^{2}$, Faqin $\mathrm{Ye}^{1}$ and Xuebao \\ Wang ${ }^{1 *}$ \\ ${ }^{1}$ School of Pharmaceutical Sciences, Wenzhou Medical University, Wenzhou 325035, ${ }^{2}$ Zhejiang Provincial Key Laboratory of \\ Aging and Neurological Disease Research, Department of Surgery, The First Affiliated Hospital of Wenzhou Medical University, \\ Wenzhou, 325000, China
}

*For correspondence: Email: wxb1981@163.com; Tel: +86-577-86699156

Sent for review: 27 March 2017

Revised accepted: 15 July 2017

\begin{abstract}
Purpose: To study the pharmacokinetics and tissue distribution of N-3-methoxybenzyl-palmitamide (MPM) derived from Lepidium meyenii (Maca)

Methods: MPM and N-benzy/palmitamide (BPM, as the internal standard, IS) were prepared by one-pot synthesis method and characterized. For the analysis of MPM in rat plasma and tissue samples, a rapid ultra-performance liquid chromatography coupled to tandem mass spectrometry (UPLC-MS/MS) method was developed and validated by optimizing sample preparation conditions and UPLC conditions. Finally, the pharmacokinetics and biodistribution of MPM after oral administration in rats were studied.

Results: The lower limit of quantification (LLOQ) and limit of detection (LOD) of the UPLC-MS/MS method were 1.2 and $5.0 \mathrm{ng} / \mathrm{mL}$, respectively. Good linear relationship of calibration curve $(r>0.9951)$ was achieved over the range of $5-5000 \mathrm{ng} / \mathrm{mL}$. In pharmacokinetics, plasma concentration-time curve of MPM showed double peaks. The highest distribution of MPM after absorption was in the stomach, followed by lung. The absorption and eliminate rate of MPM were slow in rats. In fact, MPM displayed a lung targeting property.

Conclusion: The developed UPLC-MS/MS method is suitable for plasma and tissue distribution studies of MPM in rats. The present study can provide guidance for the further development and utilization of Maca tuber.
\end{abstract}

Keywords: Macamide, Maca tuber, Lepidium meyenii, Pharmacokinetics, Tissue distribution, UPLCMS/MS

Tropical Journal of Pharmaceutical Research is indexed by Science Citation Index (SciSearch), Scopus, International Pharmaceutical Abstract, Chemical Abstracts, Embase, Index Copernicus, EBSCO, African Index Medicus, JournalSeek, Journal Citation Reports/Science Edition, Directory of Open Access Journals (DOAJ), African Journal Online, Bioline International, Open-J-Gate and Pharmacy Abstracts

\section{INTRODUCTION}

Maca, an Andean plant of the crucifer family, is heavily cultivated in some South American countries, and is also called "Peruvian ginseng" [1]. Indigenous Peruvians have traditionally used Maca for centuries as an adaptogenic plant to manage infertility, anemia, menstrual, anticancer, female hormone balance and sexual disorders [1-3]. In recent years, Based on the historical use of above facts, a series of commercial dietary supplements containing Maca have gained popularity in Japan, Europe, the US and China [4]. Numerous secondary metabolites of the Maca have been found over the years, and macamide, one of the secondary metabolites, 
was first found in Maca as the typical marker. On the chemical structure, macamide is composed of various fatty acids and their benzylamine.

In recent years, macamide has been proposed to be the biologically active substance, because of its multiple functions, such as fatty acid amide hydrolase inhibitor [5], improving sexual performance [6], endurance capacity and antifatigue [7]. So far, 22 kinds of macamide is separated and identified from Maca tuber, and N3-methoxybenzyl-palmitamide (MPM) is a representative substance $[8,9]$.

In this study, MPM was further researched on its pharmacokinetics and tissue distribution in rats, in order to deepen the understanding of macamide, and to provide guidance for the development and utilization of Maca tuber.

\section{EXPERIMENTAL}

\section{Chemicals and reagents}

Palmitoyl chloride, benzylamine and 3Methoxybenzylamine were purchased from Sinopharm Chemical Reagent Co. Ltd., China. MPM and BPM (purity > $98.0 \%$ ) were synthesized in our laboratory. Their chemical structures are presented in Figure 1. Acetonitrile of high performance liquid chromatography (HPLC) grade was acquired from Merck KGaA (Darmstadt, Germany). The other solvents and chemicals were all of analytical reagent grade. The water (resistance > $18 \mathrm{M} \Omega$ ) came from a Millipore Milli-Q water purification machine (Bedford, MA, USA).

\section{Synthesis of MPM and BPM}

Synthesis of MPM: Anhydrous diethyl ether (15 $\mathrm{mL}$ ) was placed to a round bottom flask which was attached to a Claisen adapter, and palmitoyl chloride $(4.05 \mathrm{~mL}, 0.012 \mathrm{~mol})$ was injected through the Claisen adapter septum. The mixture was stirred over $15 \mathrm{~min}$ in an ice bath. Subsequently, a mixture of 3Methoxybenzylamine $(1.99 \mathrm{~mL}, 0.018 \mathrm{~mol})$ and anhydrous diethyl ether $(1.50 \mathrm{~mL})$ was injected drop by drop into the reaction bottom flask, and then a white precipitate was formed at the end. The precipitate was washed with $10 \%$ sodium hydroxide and $10 \%$ hydrochloric acid. Finally, the product was recrystallized from ethanol with ca. $81 \%$ yield. The spectroscopic data (UV, FTIR, ESIMS) of the product was characterized. Product purity was assayed using HPLC.
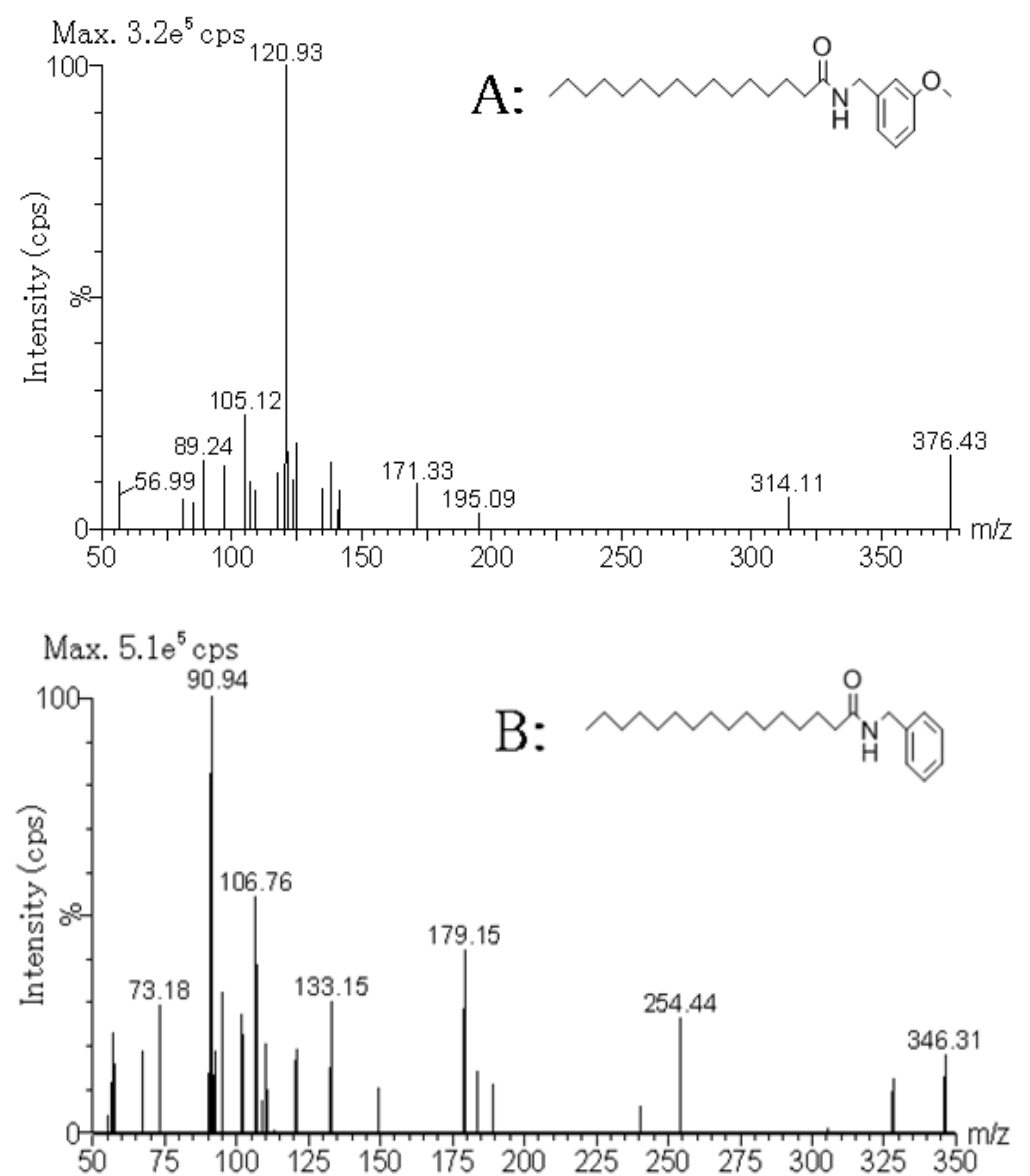

Figure 1: Production mass spectra of (A) MPM and (B) BPM, and their chemical structures 
Synthesis of BPM: BPM's synthesis process was the same with MPM, with benzylamine instead of 3-methoxybenzylamine [9].

\section{Structure confirmation of MPM and BPM}

MPM: white powder; UV (MeOH solvent): $\lambda_{\max }$ 213, $273 \mathrm{~nm}$; IR (KBr powder) $\mathrm{cm}^{-1}: U_{\max } 3294$ $(\mathrm{N}-\mathrm{H}), 2919,2849,1640(\mathrm{C}=\mathrm{O}), 1534,1469$, $1261,1154,1049,778,693 \mathrm{~cm}^{-1}$; ESIMS, $\mathrm{m} / \mathrm{z3} 76.4\left([\mathrm{M}+\mathrm{H}]^{+}\right)$.

BPM: white powder; UV (MeOH solvent): $\lambda_{\max }$ $209 \mathrm{~nm}$; IR (KBr powder) $\mathrm{cm}^{-1}: \mathrm{u}_{\max } 3306(\mathrm{~N}-\mathrm{H})$, 2917, 2849, 1638 (C=O), 1550, 1458, 1248, $1118,1081,744,698 \mathrm{~cm}^{-1}$; ESIMS, $\mathrm{m} / \mathrm{z} 346.3$ $\left([\mathrm{M}+\mathrm{H}]^{+}\right)$. The above structure data of MPM and BPM corresponded to data previously reported $[9,10]$.

\section{Instrumentation and conditions (for UPLC- MS/MS method)}

Liquid chromatography was performed on an Acquity ultra performance liquid chromatography (UPLC) unit (Waters Corp., Milford, MA, USA) with an Acquity BEH C18 column $(2.1 \times 50 \mathrm{~mm}$, $1.7 \mu \mathrm{m}$ particle size). The mobile phase consisted of acetonitrile and water containing $0.05 \%$ trifluoroacetic acid (TFA). A gradient elution program was conducted for chromatographic separation with $0.05 \%$ TFA aqueous solution (mobile phase $A$ ) and acetonitrile (mobile phase B) as follows: 0 - 0.5 $\min (30 \% A), 0.5-2.0 \min (30-10 \% A), 2.0-$ $2.5 \mathrm{~min}(10-30 \% \mathrm{~A})$. The flow rate was 0.40 $\mathrm{mL} / \mathrm{min}$ and the overall run time was $2.5 \mathrm{~min}$.

A XEVO TQD triple quadruple mass spectrometer was used to carry out mass spectrometric analysis (Waters Corp.). Multiple Reaction Monitoring (MRM) mode is used in mass analyzers with an electro-spray ionization. The MRM transitions was $m / z \quad 376.4 \rightarrow 120.9$ and $\mathrm{m} / \mathrm{z} 346.3 \rightarrow 90.9$ for MPM and IS, respectively. Data acquisition and instrument control adopted Masslynx 4.1 software.

\section{Method validation}

The method was fully validated for specificity, matrix effect, sensitivity, linearity, precision, accuracy, recovery and stability in accordance with the guidelines set by Food and Drug Administration of the United States [11]. Each validation run consisted of six replicates of quality control plasma samples (QC) or one set of calibration standards.

The specificity was determined by analysis of blank plasma samples (or blank tissue samples), blank sample spiked and the plasma sample obtained after oral administration of MPM with six different rats. Moreover, the possible interference from endogenous substances was confirmed. To evaluate the matrix effect (ME) of blank plasma (or tissues), generalized standard addition method was performed. Six different blank rat plasma (or tissues) was spiked with the analytes. ME was calculated at three QC levels (10, 100 and $1000 \mathrm{ng} / \mathrm{mL}$ ) by comparing the peak areas $(\mathrm{B} / \mathrm{C} \times 100 \%, \mathrm{~B}=$ the peak area of blank plasma samples (or tissues) spiked with analytes after extraction, $\mathrm{C}=$ the peak area of the pure standard solutions at the same concentrations). The ME of IS was calculated at the concentration $(100 \mathrm{ng} / \mathrm{mL})$ in a similar manner.

The sensitivity of the method was evaluated by determination in terms of LLOQ, and signal-tonoise ratio (SNR) was used to calculate the LLOQ. Calibration curves were obtained using these spiked calibration samples on three separate days in succession. Peak area ratio of MPM to IS was plotted against MPM concentrations. The correlation of all calibration curves was required more than 0.99. The precision and accuracy of the method were evaluated by analyzing the QC samples with known concentrations of MPM and IS (10, 100 and $1000 \mathrm{ng} / \mathrm{mL}$ ) with six replicates. The precision was defined by relative standard deviation (RSD), and the accuracy was presented as a relative error ( $R E)$.

The extraction recoveries of MPM at three QC levels $(10,1000,1000 \mathrm{ng} / \mathrm{mL})$ were calculated by comparing peak area ratios of two different sets of samples. One was the samples spiked with the MPM prior to extraction, and the other was the samples spiked with the MPM after extraction at same content. The extraction recovery of IS was determined in the same manner. The stabilities of MPM in rat sample were analyzed by using six replicates of plasma samples spiked with MPM at known concentrations (10, 100 and $1000 \mathrm{ng} / \mathrm{mL}$ ). Those samples were exposed to following four conditions. They were respectively the short-term stability (exposing samples to 25 ${ }^{\circ} \mathrm{C}$ for $24 \mathrm{~h}$ ), the freeze-thaw stability (subjecting samples to five freeze-thaw cycles), the longterm stability (samples stored at $-80^{\circ} \mathrm{C}$ for 21 days prior to extraction), and the processed sample stability (samples stored at $4{ }^{\circ} \mathrm{C}$ for 72 h).

\section{Animals}

The Sprague-Dawley rats $(210 \pm 20 \mathrm{~g})$ were provided by the Laboratory Animal Center of Wenzhou Medical University, and were 
performed to study the pharmacokinetics and biodistribution of MPM. Before the experiment, the diet was banned for $12 \mathrm{~h}$, but the water was free. The animal care and use committee of our university approved the experiment protocols and procedures (ethical approval code: WMU20160817). These experiments are in line with rules in the $\mathrm{NIH}$ Guide for the Care and Use of Laboratory Animals [12].

\section{Pharmacokinetics study}

Six rats were used for pharmacokinetics study at a dose of $80 \mathrm{mg} / \mathrm{kg}$ MPM prepared with $1.0 \%$ sodium carboxymethylcellulose. Collect whole blood $(0.5 \mathrm{ml})$ from the caudal vein into plastic centrifuge tubes (pretreated with heparin sodium) at pre-dose, $0.08,0.16,0.25,0.5,1,2,4,8,12$, 24 and $48 \mathrm{~h}$ after oral administration of MPM. Then the whole blood was centrifuged timely at $3000 \mathrm{~g}$ for $10 \mathrm{~min}$ for isolation of the plasma. Those samples were stored at $-80{ }^{\circ} \mathrm{C}$ until further preparation.

\section{Tissue distribution studies}

Eighteen SD rats were randomly assigned to three groups with six rats per group. They were used for tissue distribution study at a dose of $80 \mathrm{mg} / \mathrm{kg}$ MPM prepared with $1.0 \%$ sodium carboxymethylcellulose. Rats were sacrificed under ether anesthesia at 0.5, 2, $12 \mathrm{~h}$ after dosing and brain, lung, heart, stomach, kidney, liver, spleen or reproductive organ were harvested. All of the samples were timely stored at $-80^{\circ} \mathrm{C}$ until further preparation.

\section{Sample preparation}

The $250 \mu \mathrm{L}$ plasma sample (or $0.25 \mathrm{~g}$ milled tissue sample) was added to a $5 \mathrm{~mL}$ centrifuge tube, and $5 \mu \mathrm{L}$ of IS methanol solution $(5 \mu \mathrm{g} / \mathrm{mL})$ and $2 \times 2.5 \mathrm{~mL}$ ethanol solution (containing 0.2 $\%$ formic acid) was added. Then the tubes were vortexed for $1.0 \mathrm{~min}$ and centrifuged at 5,000 g for $10 \mathrm{~min}$. The twice extracted solutions were merged and concentrated. It was purified by pure silica solid-phase extraction (SPE) column washed with $2 \times 1 \mathrm{~mL}$ of water, $1 \mathrm{~mL}$ of acetonitrile - water (20:80, v/v) and finally with $3 \times 1 \mathrm{~mL}$ of acetonitrile, and the eluate was blowdried with nitrogen at $50{ }^{\circ} \mathrm{C}$ and the residue was redissolved in $250 \mu \mathrm{L}$ of ethanol. This extracted solution was injected into UPLC/MS system.

\section{Data analysis}

After UPLC/MS determination, the peak areas of analytes were integrated, and the peak area ratio of MPM to IS was calculated. Parameter values were calculated and expressed with mean \pm SD (upper and lower CI $95 \%$ ). Precision RSD (\%) = $\mathrm{SD} / \mathrm{mean} \times 100$. Accuracy RE $(\%)=$ (conc. measured - conc. spiked)/conc. spiked $\times 100$.

\section{RESULTS}

\section{Optimized sample preparation and UPLC conditions}

Extract reagent played a critical role when the sample was prepared to get higher recovery and lower matrix interferences for the analyte. The reagent effect on extraction yield was investigated, including methanol, alcohol, acetonitrile, acetone and n-hexane. In order to study the effect of $\mathrm{pH}$, each of these solvents added $0.2 \%$ formic acid and $0.2 \%$ ammonia respectively. Ethanol solution (containing $0.2 \%$ formic acid) had the highest recovery rate, but also had a high matrix interference especially in tissue sample. In order to remove the matrix interference, SPE method was adopted, and it was valid that plasma sample and tissue sample all had negligible matrix interference.

To achieve more efficient separation of isolates, chromatographic conditions of chromatographic column and mobile phase were optimized. We investigated four mobile phases, and acetonitrile - water (containing $0.05 \%$ TFA) resulted in the production of better peaks due to higher sensitivities. Furthermore, We tested three types of chromatographic column with different polarity. Finally Acquity BEH C18 column $(2.1 \times 50$ mm, $1.7 \mu \mathrm{m}$ particle size) produced better separation within a short time. In addition, we optimized mobile phase gradient elution with acetonitrile water containing $0.05 \%$ TFA in $400 \mu \mathrm{L} / \mathrm{min}$ flow rate, within $2.5 \mathrm{~min}$.

\section{Specificity and matrix effect}

Three samples of the representative extract ion chromatograms (XIC) from mass spectrometry were shown in Figure 2. Three samples of blank plasma sample, plasma sample spiked at LLOQ level and plasma sample collected 15 min after oral administration represented three different concentrations, and endogenous interferences for the analyte were all not observed. The matrix effect for MPM at concentrations of 10, 100 and $1000 \mathrm{ng} / \mathrm{mL}$, were $95.1 \pm 3.7 \%, 106.4 \pm 4.2 \%$ and $102.7 \pm 4.3 \%(n=6)$, respectively. The ME for IS $(100 \mathrm{ng} / \mathrm{mL})$ was $105.3 \pm 3.6 \%(\mathrm{n}=6)$. It followed that matrix effect from plasma was negligible in this method.

The use of SPE method resulted in a significant reduction of endogenous interferences of tissue 
samples. The extract ion chromatograms of tissue sample were similar to the plasma samples'.

\section{Linearity and sensitivity}

Using weighted $\left(1 / x^{2}\right)$ linear regression analysis, we established calibration curves based on the peak area ratio of MPM to IS. MPM presented a good linear relationship with the range of 5 $5000 \mathrm{ng} / \mathrm{mL}$. The regression equations, the linear ranges, and the correlation coefficients for MPM in plasma and tissues are listed in Table 1. The LLOQ of MPM in plasma and tissue was $5 \mathrm{ng} / \mathrm{mL}$ with the RSD and RE of 8.5 and $5.6 \%$,
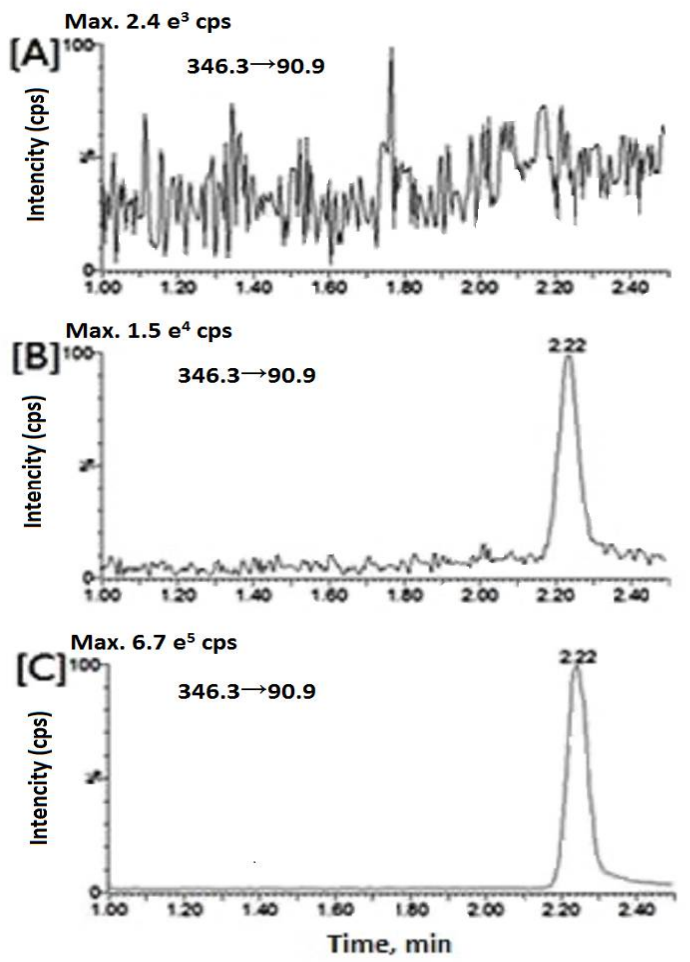

respectively. The LOD of MPM in plasma and tissues was $1.2 \mathrm{ng} / \mathrm{mL}$.

\section{Precision, accuracy and recovery}

RSD taken as the measures of precision for QCs was calculated over three days of validation tests at three concentration levels. In the same way, relative error $(\mathrm{RE})$ was taken as the measures of accuracy. The results of the precision, accuracy and recovery were showed in Table 2 . All results of precision for the samples were in the range of $-9.2 \sim 11.8 \%$ within the acceptable criteria of \pm $15 \%$. These data demonstrated that the assay was reproducible and accurate for MPM determination in rat plasma or tissue samples.

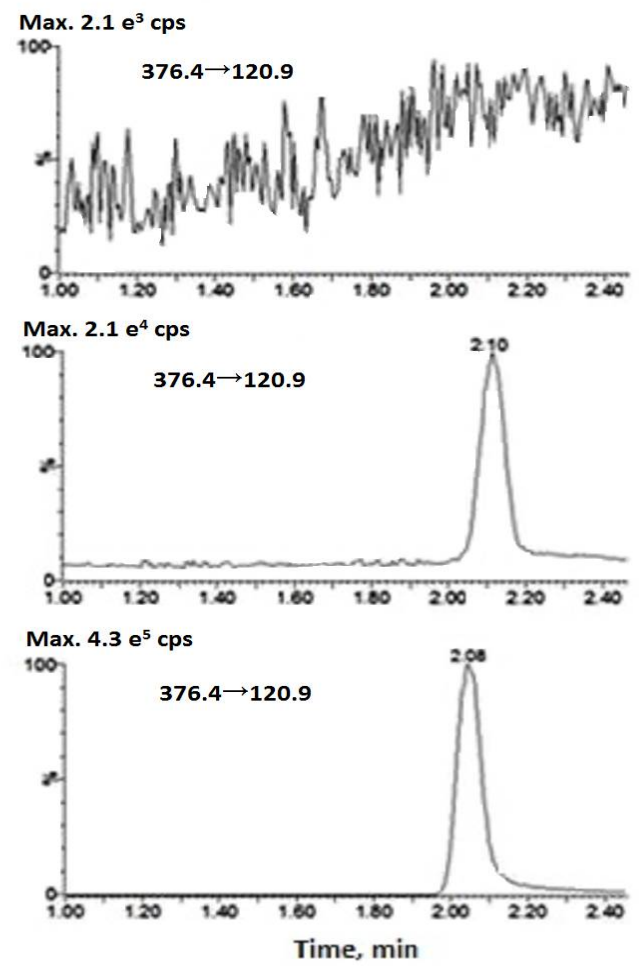

Figure 2: Representative XIC from mass spectrometry: (A) a blank plasma sample; (B) plasma sample spiked at LLOQ level; (C) plasma sample collected $15 \mathrm{~min}$ after oral administration of MPM at the dose of $80 \mathrm{mg} / \mathrm{kg}$. The XIC showed MPM at $\mathrm{m} / \mathrm{z} 376.4 \rightarrow 120.9$ and IS at $\mathrm{m} / \mathrm{z} 346.3 \rightarrow 90.9$

Table 1: Calibration parameters for MPM in rat plasma and tissues

\begin{tabular}{llcc}
\hline Sample & Regression equation & $\begin{array}{c}\text { Correlation } \\
\text { coefficient }(\mathbf{r})\end{array}$ & $\begin{array}{c}\text { Linear range } \\
(\mathbf{n g} / \mathbf{m L})\end{array}$ \\
\hline Plasma & $\mathrm{y}=0.0001562321 x+0.00024597$ & 0.9969 & $5-5000$ \\
Brain & $\mathrm{y}=0.0001610634 x+0.00032861$ & 0.9991 & $5-5000$ \\
Lung & $\mathrm{y}=0.0001547624 x+0.00021632$ & 0.9951 & $5-5000$ \\
Heart & $\mathrm{y}=0.0001496412 x+0.00023037$ & 0.9959 & $5-5000$ \\
Stomach & $\mathrm{y}=0.0001595638 x+0.00019053$ & 0.9977 & $5-5000$ \\
Kidney & $\mathrm{y}=0.0001475628 x+0.00020531$ & 0.9969 & $5-5000$ \\
Liver & $\mathrm{y}=0.0001555281 \mathrm{x}+0.00029651$ & 0.9992 & $5-5000$ \\
Spleen & $\mathrm{y}=0.0001630921 \mathrm{x}+0.00017976$ & 0.9987 & $5-5000$ \\
Reproductive & $\mathrm{y}=0.0001450331 \mathrm{x}+0.00013992$ & 0.9971 & $5-5000$ \\
organ & & & \\
\hline
\end{tabular}

Note: $\mathrm{y}=$ the peak area ratio of MPM to IS; $\mathrm{x}=$ the concentration of MPM 
Table 2: Precision, accuracy and recovery for the determination of MPM in rat sample $(n=6)$

\begin{tabular}{|c|c|c|c|c|c|c|}
\hline \multirow{2}{*}{ Sample } & \multirow{2}{*}{$\begin{array}{l}\text { Conc. spiked } \\
(\mathrm{ng} / \mathrm{mL})\end{array}$} & \multicolumn{2}{|c|}{ RSD (\%) } & \multicolumn{2}{|c|}{ RE (\%) } & \multirow{2}{*}{$\begin{array}{c}\text { Recovery } \\
(\%)\end{array}$} \\
\hline & & intra-day & inter-day & intra-day & inter-day & \\
\hline \multirow[t]{3}{*}{ Plasma } & 10 & 10.1 & 10.6 & -8.6 & 7.8 & 82.3 \\
\hline & 100 & 5.5 & 6.1 & 6.7 & 5.5 & 87.8 \\
\hline & 1000 & 2.6 & 3.2 & 2.4 & -3.3 & 85.1 \\
\hline \multirow[t]{3}{*}{ Brain } & 10 & 9.3 & 11.2 & -8.2 & 9.2 & 80.3 \\
\hline & 100 & 6.0 & 6.4 & 6.2 & -6.0 & 81.5 \\
\hline & 1000 & 3.2 & 3.6 & 2.7 & -3.2 & 86.2 \\
\hline \multirow[t]{3}{*}{ Lung } & 10 & 9.2 & 10.1 & -8.7 & 7.9 & 80.9 \\
\hline & 100 & 5.1 & 6.3 & 7.2 & -6.8 & 83.8 \\
\hline & 1000 & 3.9 & 2.8 & 2.1 & -2.9 & 84.2 \\
\hline \multirow{3}{*}{ Heart } & 10 & 8.7 & 10.3 & -9.2 & 8.3 & 82.1 \\
\hline & 100 & 6.6 & 6.1 & 7.8 & -5.7 & 88.8 \\
\hline & 1000 & 2.1 & 3.7 & 3.0 & -3.2 & 85.2 \\
\hline \multirow[t]{3}{*}{ Stomach } & 10 & 10.5 & 12.3 & -9.1 & 8.6 & 90.4 \\
\hline & 100 & 6.5 & 5.1 & 7.3 & 6.7 & 84.8 \\
\hline & 1000 & 3.9 & 4.1 & 3.6 & -3.1 & 87.2 \\
\hline \multirow[t]{3}{*}{ Kidney } & 10 & 9.7 & 9.6 & -3.2 & 7.3 & 80.9 \\
\hline & 100 & 5.1 & 6.5 & 7.8 & -5.3 & 85.8 \\
\hline & 1000 & 4.9 & 3.6 & 2.7 & -3.9 & 84.1 \\
\hline \multirow[t]{3}{*}{ Liver } & 10 & 9.5 & 10.2 & -8.2 & 7.4 & 83.4 \\
\hline & 100 & 5.9 & 6.4 & 5.9 & 5.8 & 83.8 \\
\hline & 1000 & 2.3 & 3.7 & 2.8 & -3.3 & 84.7 \\
\hline \multirow[t]{3}{*}{ Spleen } & 10 & 9.9 & 9.8 & -8.0 & 7.7 & 91.4 \\
\hline & 100 & 5.4 & 5.7 & 5.5 & 5.4 & 85.8 \\
\hline & 1000 & 3.0 & 3.2 & 4.6 & -3.7 & 85.2 \\
\hline Reproductive & 10 & 9.9 & 11.8 & -8.4 & 9.2 & 87.1 \\
\hline \multirow[t]{2}{*}{ organ } & 100 & 6.5 & 7.3 & 6.8 & -6.9 & 82.4 \\
\hline & 1000 & 3.9 & 3.9 & -4.7 & 4.8 & 83.1 \\
\hline
\end{tabular}

In rat plasma and tissue samples, the minimum recovery of MPM was $80.3 \%$. The recovery of the IS $(100 \mathrm{ng} / \mathrm{mL})$ was $83.7 \%$ or higher. The above results indicated that sample preparation method could obtain satisfying extraction efficiency for MPM in rat plasma and tissue sample.

\section{Stability}

The stability of MPM in rat sample were evaluated by analyzing six replicates of rat samples which were all exposed to long-term stability, short-term stability freeze-thaw stability, and the processed sample stability. The reinspection yield $\{R I Y=$ (conc. measured later/conc. measured first) $\times 100 \%$ was used to express the stability. Calculated results showed that the RIY was in the range of $90.5-111.2 \%$. The data indicated that there was no significant degradation and the established methods were acceptable when samples of MPM were exposed to different conditions. The method was successfully applied to determine the concentration of MPM in rat's plasma and tissue samples in the following experiments.

\section{Plasma pharmacokinetics}

The mean plasma concentration-time profile is shown in Figure 3 and the primary pharmacokinetic parameters are summarized in Table 3. Plasma concentration-time curve of MPM showed double peaks. The peak plasma concentration of MPM after oral administration at $0.5 \mathrm{~h}$ was $600.3 \pm 167.1 \mathrm{ng} / \mathrm{mL}$. The area under the curve $\left(\mathrm{AUC}_{0 \rightarrow \mathrm{t}}\right)$ and elimination half-life of MPM in plasma was $6485.75 \pm 737.72 \mathrm{ng} / \mathrm{mL} \cdot \mathrm{h}$ and $7.44 \pm 1.12 \mathrm{~h}$, respectively.

\section{Tissue distribution}

The tissue distribution of MPM in rats after oral administration of $80 \mathrm{mg} / \mathrm{kg}$ dose is presented in Figure 4. The MPM concentrations in stomach after $0.5,2$ and $12 \mathrm{~h}$ were $3105.0 \pm 267.1$, $2782.2 \pm 205.6$ and $404.5 \pm 53.1 \mathrm{ng} / \mathrm{g}$, respectively. The MPM concentrations in lung were $300.5 \pm 17.4,2200.7 \pm 152.9$ and $415.2 \pm$ $43.3 \mathrm{ng} / \mathrm{g}$, respectively. The MPM concentrations in spleen were $205.3 \pm 15.8,769.3 \pm 94.1$ and $175.2 \pm 24.1 \mathrm{ng} / \mathrm{g}$, respectively. The MPM concentration in other tissues of brain, heart, kidney, liver, reproductive organ was low, and even its highest concentration also was under $250 \pm 37.4 \mathrm{ng} / \mathrm{g}$.

\section{DISCUSSION}

MPM is a hydrophobic organic compound with a long aliphatic chain. Usual method to prepare biological sample with adding $200 \mu \mathrm{L}$ methanol 
or acetonitrile to $100 \mu \mathrm{L}$ plasma sample was tried and infeasible because of the low recovery rate. Several kinds of reagents with different volume were investigated. Finally, high proportion of extracting solution and addition of formic acid were adopted together, to raise the extraction rate and recovery rate of MPM. The optimum combination ratio was $1: 20(\mathrm{v}: \mathrm{v})$ corresponding to biological sample : ethanol (containing $0.2 \%$ formic acid).

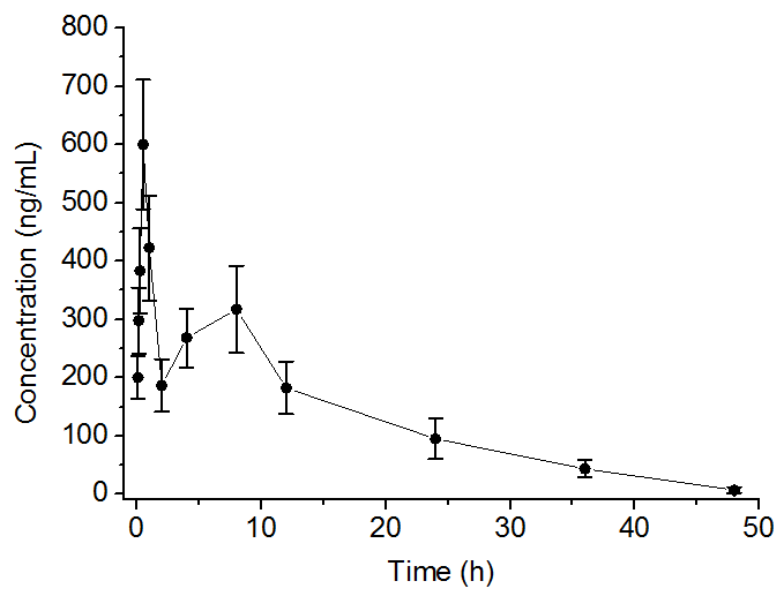

Figure 3: Mean plasma concentration-time plots at a single dose of $80 \mathrm{mg} / \mathrm{kg}$ MPM of oral administration in rats $(n=6)$

Table 3: The main pharmacokinetic parameters at a single dose of $80 \mathrm{mg} / \mathrm{kg}$ MPM of oral administration in rats $(n=6)$

\begin{tabular}{ll}
\hline Parameter & Mean \pm SD \\
\hline Absorption & \\
$\mathrm{T}_{\max }(\mathrm{h})$ & $0.50 \pm 0.18$ \\
$\mathrm{C}_{\max }(\mathrm{ng} / \mathrm{mL})$ & $600.3 \pm 167.1$ \\
Elimination & \\
$\mathrm{T}_{1 / 2 \mathrm{el}}(\mathrm{h})$ & $7.44 \pm 1.12$ \\
$\mathrm{AUC}_{0 \rightarrow \mathrm{t}}(\mathrm{ng} / \mathrm{mL} \cdot \mathrm{h})$ & $6485.75 \pm 737.72$ \\
$\mathrm{AUC}_{0 \rightarrow \infty}(\mathrm{ng} / \mathrm{mL} \cdot \mathrm{h})$ & $6560.91 \pm 807.36$ \\
$\mathrm{~V}_{\mathrm{d}}(\mathrm{L} / \mathrm{kg})$ & $130.98 \pm 15.29$ \\
$\mathrm{CL}(\mathrm{L} / \mathrm{h} / \mathrm{kg})$ & $12.19 \pm 1.92$ \\
\hline
\end{tabular}

In pharmacokinetic experiment, plasma concentration-time curve of MPM presented a double peak, probably because the rat's organization concentration of MPM is much higher than its plasma's, which could cause MPM from organization transporting to plasma [13]. We inferred there might be distribution, reabsorption and entero-hepatic circulation in rats [14]. Pharmacokinetic of MPM could be evaluated by two compartment model. The elimination half-life of $7.44 \pm 1.12 \mathrm{~h}$ showed that the elimination of MPM was slow in rats.

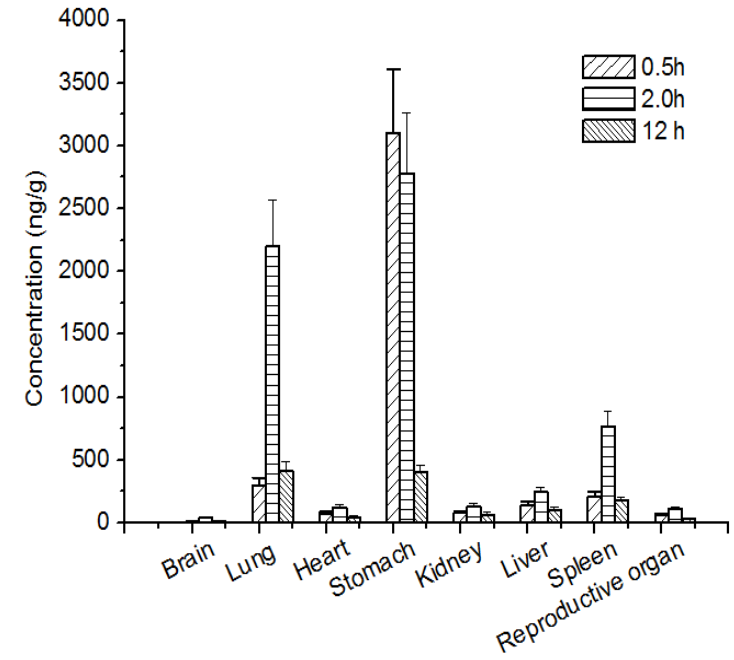

Figure 4: Rat tissue concentration of MPM after single oral administration of $80 \mathrm{mg} / \mathrm{kg}$ dose

The value of AUC $(6485.75 \pm 737.72 \mathrm{ng} / \mathrm{mL} \cdot \mathrm{h})$ is not significant with a dose of $80 \mathrm{mg} / \mathrm{kg}$ compared to other reported drugs [15-17]. Unfortunately, there are missing data of absolute bioavailability, because direct intravenous drug delivery was unsuccessful in this experiment. By intravenous administration of MPM ethanol solution (at the dose of $1 \mathrm{mg} / \mathrm{kg} \mathrm{MPM}$ ), all the rats died within 5 min. After excluding the toxicity of the MPM [18], the poor solubility of MPM in blood that could lead MPM to precipitating and blocking the blood vessels might be the main cause of death of the rats.

The results of tissue distribution showed that stomach had the dominant distribution, and that the absorption of MPM in stomach was slow and incomplete because of a higher concentration at $12 \mathrm{~h}$ after dosing. The second was in lung with relatively high concentration, even higher than the concentration of stomach at the point of $12 \mathrm{~h}$. The phenomenon showed that MPM in lung was eliminated at a slow rate. Lipophilic MPM could remained in lung tissue with a longer time, because lung tissue has good lipophicity [13]. Thus, MPM has a high targeting property and is widely distributed in other tissues with low concentration.

\section{CONCLUSION}

The developed UPLC-MS/MS method is suitable for plasma and tissue distribution studies of MPM in rats. The MPM pharmacokinetic and tissue distribution data obtained would provide guidance for the further development and utilization of Maca tuber. 


\section{DECLARATIONS}

\section{Acknowledgement}

This work was supported by Foundation of Zhejiang Provincial Education Department Project (Grant No Y201534182) and Wenzhou Municipal Science and Technology Bureau (no. Y20150107).

\section{Conflict of Interest}

No conflict of interest associated with this work.

\section{Contribution of Authors}

The authors declare that this work was done by the authors named in this article and all liabilities pertaining to claims relating to the content of this article will be borne by them.

\section{Open Access}

This is an Open Access article that uses a funding model which does not charge readers or their institutions for access and distributed under the terms of the Creative Commons Attribution License (http://creativecommons.org/ licenses/by/ 4.0) and the Budapest Open Access Initiative (http://www.budapestopena ccessinitiative.org/read), which permit unrestricted use, distribution, and reproduction in any medium, provided the original work is properly credited.

\section{REFERENCES}

1. Hudson T. Maca: new insights on an ancient plant. Integr Med 2008; 7: 54-57.

2. Wang $Y$, Wang $Y$, Mcneil B, Harvey LM. Maca: An Andean crop with multi-pharmacological functions. Food Res Int 2007; 40 (7): 783-792.

3. Lentz AC, Carson III CC, Marson L. Does the new herbal supplement maca enhance erectile function or female sexual function? Semin Prev Altern Med 2006; 2: 85-90.

4. Li G, Ammermann U, Quirós C. Glucosinolate contents in maca (Lepidium peruvianum; chacón) seeds, sprouts, mature plants and several derived commercial products. Econ Bot 2001; 55: 255-262.

5. Almukadi $H, W u H$, Böhlke M, Kelley CJ, Maher TJ, PinoFigueroa $A$. The macamide N-3-methoxybenzyllinoleamide is a time-dependent fatty acid amide hydrolase (FAAH) inhibitor. Mol Neurobiol2013; 48 (2): 333-339.
6. Zheng $\mathrm{BL}, \mathrm{He} \mathrm{K}, \mathrm{Kim} \mathrm{CH}$, Rogers $L$, Shao $Y$, Huang $Z Y$, Lu Y, Yan SJ, Qien LC, Zheng QY. Effect of lipidic extract from Lepidium meyenii on sexual behavior in mice and rats. Urology 2000; 55 (4): 598-602.

7. Yang $Q$, Jin $W, L v X$, Dai $P$, Ao $Y$, Wu M. Effects of macamides on endurance capacity and anti-fatigue property in prolonged swimming mice. Pharm Biol 2016; 54 (5): 827-834.

8. Chen J, Zhao B. Research progress on macamides. Chin Tradit Herbal Drugs 2015; 46 (21): 3284-3288.

9. Mccollom MM, Villinski JR, Mcphail KL., Craker LE, Gafner S. Analysis of macamides in samples of Maca (Lepidium meyenii) by HPLC-UV-MS/MS. Phytochem Anal 2005; 16 (6): 463-469.

10. Muhammad I, Zhao J, Dunbar DC, \& Khan IA. Constituents of Lepidium meyenii, 'maca'. Phytochemistry 2002; 59 (1): 105-110.

11. Food \& Drug Administration. Draft guidance for industry: Bioanalytical Method Validation. US Department of Health and Human Services 2013. Available at <http://www.fda. gov/downloads/ Drugs/Guidance Compliance Regulatory Information/Guidances/ UCM368107.pdf>.

12. Council N. Guide for the Care and Use of Laboratory Animals: Eighth Edition. Guide for the Care \& Use of Laboratory Animals 2010; 327 (1):41-48.

13. Hu YL, Chen C, Zhou ZY, Gao CL. Comparative study of pharmacokinetics and tissue distribution of 8cetylberberine and berberine in rats. Acta Pharm Sin 2014; 49 (11): 1582-1587.

14. Deng Y, Liao Q, Li S, Bi K, Pan B, \& Xie Z. Simultaneous determination of berberine, palmatine and jatrorrhizine by liquid chromatography-tandem mass spectrometry in rat plasma and its application in a pharmacokinetic study after oral administration of coptis-evodia herb couple. J Chromatogr B Analyt Technol Biomed Life Sci 2008; 863 (2): 195-205.

15. Chen LG, Yang SP, Liu ZZ, Zhang LJ, Lin YY, Chen ML, Zhou Q, Wen CC, Wang XB. Pharmacokinetic Study of Macitentan in Rat Plasma by Ultra Performance Liquid Chromatography-Tandem Mass Spectrometry. Lat Am J Pharm 2015; 34 (7):1411-1416.

16. Wang JY, Zheng $D D$, Wang $Y Z$, Zhang $C$, Sun $X M$. Pharmacokinetics study of Erhuang decoction extracts in rats by HPLC-MS/MS. J Chromatogr B 2017; 1059: 35-42.

17. Chen LG, Yang SP, Liu ZZ, Zhang LJ, Lin YY, Chen ML, Zhou Q, Wen CC, Wang XB. Pharmacokinetic Study of Macitentan in Rat Plasma by Ultra Performance Liquid Chromatography-Tandem Mass Spectrometry. Lat Am J Pharm 2015; 34 (7):1411-1416.

18. Valerio LG, Gonzales GF. Toxicological aspects of the South American herbs cat's claw (Uncaria tomentosa) and maca (Lepidium meyenii): a critical synopsis. Toxicol Rev 2005; 24: 11-35. 